\title{
The Innovation of the Social Management from the Perspective of People's Livelihood
}

\author{
Zhiyuan $\mathrm{HU}^{1,}$, Shihua $\mathrm{LI}^{2, \mathrm{~b}}$ \\ ${ }^{1}$ School of Marxism, Hohai University, Nanjing 210098, China \\ ${ }^{2}$ School of management and engineering, Nanjing University, Nanjing 210093, China \\ ahubin0072@126.com, ${ }^{b}$ lishihua88@163.com
}

Keywords: People's Livelihood; Social Management; Innovation

\begin{abstract}
Strengthening the innovation of society management is not only the problem of people's livelihood, but the problem of development. At present, regarding the improvement of the people's livelihood as the fundamental target and strengthening the innovation of social management has become an important theoretical and practical issue. We must improve people's livelihood so as to make people enjoy fully the achievements of economic and social development. Therefore, the innovation of social management must focus on improving people's livelihood.
\end{abstract}

\section{Introduction}

The innovation of social management refers to the activities or process of activities of achieving new goal of social management through improving and reforming the traditional management mode and the corresponding management method to construct a new social management mechanism and system in the existing social conditions. It must use the existing resources and experience to conduct the innovation of social management according to the development situation of politics, economy and society. The goal of social management innovation is to make the society form a good order and have more ideal benefit of economy and politics, which makes people to enjoy fully the achievements of economic and social development. Therefore, the social management innovation should be carried out on improving people's livelihood.

\section{Rational understanding on social management innovation at perspective people's livelihood}

The improvement of people's livelihood is an inevitable of social management innovation; meanwhile, it is also the idea of social and the value of social management innovation.

\subsection{The improvement of people's livelihood is an inevitable of social management innovation}

There have been many new social problems and Contradictions such as a lot of imbalances and no harmonious phenomenon at the same time Chinese people have made great achievements since the reform and opening up in China. The objective of the social management is to solve the social problems, resolve social conflicts, promote social justice and maintain social stability. Therefore, in order to maintain social stability and harmonious development, we must improve the livelihood of the people and social management efficiency better, which can establish a solid foundation for the reform and innovation of the social management system and mechanism.

\subsection{The improvement of people's livelihood is the idea of social management innovation}

Idea decides the success and failure of the social management innovation. At present, although the social management innovation has been strengthening with different degree, there are many prominent problems such as deficiencies of the management and lack of service. Among these, the concept "official standard", "power standard", "government standard" of the government departments is still serious, the idea and way of the social organization and management are reflecting the administrative color obviously. In Germany, the "civic office" throughout the whole territory is a typical example which achieves the idea of the social management "in service". The "Civil office" is based on the e-government platform, directly facing the ordinary citizen, which is a grass-roots unit to provide government services and social management services for citizens' daily lives [1]. We should learn from the "people-oriented" way of thinking and the service idea, which 
integrates with the social management and service.

\subsection{The improvement of people's livelihood is the value of social management innovation}

At the provincial main leading cadres of social management and innovation seminar, General Secretary Jintao Hu stressed: "The social management is the management of people and service in the final analysis, which relates to the vital interests of the masses. We must always adhere to the people-oriented, governing for the people and we effectively implement the purpose of the service putting one's heart and soul into the fundamental for people. We must realize, safeguard and develop the fundamental interests of the people." These fully show that solving the people's livelihood problem is the basic starting point and foothold of the social management innovation.

\section{The significance of social management innovation at the perspective of people's livelihood}

The innovation of social management oriented to the livelihood of the people reflects the essence of the nature and purpose of the Communist Party of China. It is not only a necessary requirement to implement the scientific outlook on development and an important foundation for the construction of socialist harmonious society, but the realistic need of the social civilization progress.

\subsection{Reflecting the essence of the nature and purpose of the Communist Party of China}

All the tasks and responsibilities of The Chinese Communist Party are to realize, safeguard and develop the interests of the masses. Only solving the problem of the people's livelihood continually, can we win the trust and support of the people. Only winning the people's trust and support, the ruling status of the party can be as steady as Mount Tai. Therefore, strengthening social management innovation must be people-oriented, which must put the livelihood of the people in a more prominent position. The Chinese Communist Party must concern about the people's benefits and think of people's livelihood, so as to achieve truly the target "power for the people, love the people, benefits for the people". Only in this way, we can practice the fundamental purpose of the party better, and consolidate the ruling status of the party.

\subsection{Necessary requirement to implement the scientific outlook on development}

The core of scientific outlook on development is "people-oriented", pursuing a comprehensive, coordinated and sustainable development. People-oriented is to continuously meet the people's growing material and cultural needs and to improve the people's happiness index. "Development is for the people, by the people and to let people share the fruits of development". This is one of the most brilliant expositions in the report at the 17th National Congress of the Communist Party of China, and it is starting point and end-result of scientific outlook on development. The idea of people-oriented is to adhere to the people-oriented fundamentally and it is also inevitable requirement to implement the scientific outlook on development. Solving the people's livelihood problem well and implementing the "Five" objectives of the people's livelihood is an important symbol on the measure of the degree of implementing scientific outlook on development [2].

\subsection{Important foundation for the construction of socialist harmonious society}

The harmonious society is not only the aim of our party, but also the common social ideal of all our ethnic group people. At present, China is in a golden period of the development and also the period of prominent contradictions. The reform has brought about the diversification of social interests structure, meanwhile the relatively reasonable mechanism to adjust interest relations has not been yet formed because of the social system reform lagging. Such as the widening gap between rich and poor, difficult to go to school and see a doctor and difficult employment and so on is being more prominent problems. Therefore, only by speeding up the economic development, paying attention to the livelihood of all the people and taking more effective measures to improve the status of the masses living conditions, we can make the all people share in the fruits of reform and opening up and development and we can achieve social stability and harmony in the end.

\section{The basic strategy of social management innovation at the perspective of people's livelihood}

The innovation of social management must regard improving the livelihood of the people as the important goal. Therefore, we must firmly grasp the following basic strategy. 


\subsection{To pay attention to coordination of civil society change and social management}

In recent years, the latest progress of comparative development and public management research shows that the coordinated development of state and the society can complement each other. The economic sociologist Peter Evans in California University wrote a Book that "national and social coordination theory", thinking: the success of the government, on the one hand, can push for social development of a long-term policy looking far ahead from a high plane beyond our society special interest [3]. On the other hand, the state must also remain interaction with the same social organizations to promote its policy effectively. Therefore, when we design the mechanism innovation path of the social management system, we must break the traditional model with the government or public institutions only authoritative body. The participation in public affairs management can be not only a public institution, and can also be private or public agencies and organizations. It attaches great importance to the cooperatives between agencies and organizations. We can implement effective management for the public affairs through establishing a management mechanism of upper and lower interaction and power bidirectional operation.

\subsection{Grasping the unity of improving people's livelihood and social management innovation}

The unity is a necessary requirement to achieve the development of the social management science. The essence of the social management innovation is to mobilize fully the enthusiasm of the masses of the people's master spirit, to develop their enthusiasm and creativity, to improve the scientific level of the social management. If a community is to maintain the most basic cohesion, stability and harmony, it must control effectively the social interest differentiation and interest conflict without triggering antagonism conflict so as not to jeopardize the interests of society as a whole community. For the local government of all levels, it is very important to the improvement of people's livelihood and social unity of management innovation. We must make arrangements for the system and policy of improving people's livelihood and establish and improve various social security systems aiming to protect the interests of vulnerable groups in order to make citizens fully enjoy the fruits of social development and to improve the level of social security and management.

\subsection{Exerting enthusiasm of the diversification governance subject of the social management}

The Communist Party of Italy founder Gramsci put forward the theory framework of a society structure. He thought that a society is composed of government, market and civil society three pillars, which the three parts mutually balanced societies are reasonable. The United States government formed a three-dimensional management mode and characteristics of the social management on the social management. Through the establishment of the sound and perfect social security system, the government makes full use tilt means of fiscal expenditure to redistribute the social wealth and to maximize the social justice. At the same time, the government plays the role of a bridge between many social organizations and non-profit organizations so as to enhance the level of social management from self-government level [4]. Therefore, we should pay attention to integrate the functional advantages of social management subjects so as to form the structure of social management of the diversified governance.

\section{The basic measures of social management innovation at perspective of people's livelihood}

The current economics is changing rapidly in the world. Comparing with the economic development, social management in China is still relatively weak. The management idea is backward and the management system and mechanism is not perfect yet. Therefore, it is the only route improving social management level to promote the innovation of social management methods and means in a high starting point and the maximum to meet people's needs and expectations.

\subsection{Highlighting the humane of the management tool}

The management tool is a very important aspect of social management. In contemporary, western countries also use some of the large number of humanized administration tools such as the market mechanism, the performance contract and consultative management, apart from the two most basic management tool of the compulsory and license. In the social management innovation, China must learn from foreign experience and use the management tools scientifically. It means that we must prevent from evolving the social management and service simply as a social control. At the same 
time, we must pay attention to the interests of the citizens, expression of interests and maximize the maintenance of the fundamental interests of the people. Finally, we will establish a multi-dimensional social governance structure gradually.

\subsection{Advancing the legalization of the management mechanism}

It is very necessary to make clear the legal status of subject of interest in law, and to establish the interest competition rules and to perfect the safeguard mechanism such as interest coordination mechanism, the expression mechanism, conflict mediation mechanism, rights protection mechanism. Through the legal security of the management mechanism, we can achieve the social management target in good legal environment. We can protect the interests of the masses of the people through fairness and justice. At the same time, we must also make clear legal provisions on people's participation in the legal level so as to guide and mobilize the broad masses of the people and all kinds of social organizations to participate in the social management.

\subsection{Strengthening the diversification of the management main body}

In the management of social participation, by emphasizing the participation of the civic and social organizations and paying attention to self - construction and development of civil society, we can give people the self-management, self-control power and space. In the performance of the functions of social management, the main function of the government social management is to serve the society and to provide the same high quality living conditions for the people by putting the public interests as the center and achieving the social fairness as its mission. At the same time, by exerting the government, market and social interaction, we can forms management community. And by forming a series of identity relation network in a long-term relationship, cooperation, interaction, we should form "politics - economy - society" [5]. Ternary main mode of civil society eventually.

\section{Conclusion}

In short, the government should fully implement the performance management measures of the public administration. The city government is not only the organizer and director of social management, but also the ultimate responsibility of social management of the city. By learning from other country's social management experience, we can establish and improve the performance evaluation system of government social management science from the responsibilities, management efficiency and the public satisfaction so that we can implement the performance management and improve management efficiency. Meanwhile, in order to maximize the interests of the citizens, the government should further improve the social benefit conformity mechanism, the social insurance, social relief, the social welfare and the philanthropy of the social security system yet.

\section{Acknowledgement}

This work was financially supported by the scientific research innovation project in Jiangsu province in 2012 (CXZZ12_0222).

\section{References}

[1] Gong Weibin. The ten Relationships of Social Management and Innovation [J].Secretarial Work. 2011 (07).

[2] LiZhang. To solve the Livelihood's Problems by Innovating the Social Management [J]. Theory Guide. 2011 (9).

[3] Tao Guogen. The Studies of Social Synergy in the Social Management System Reform --from

the Perspective of Social Capital Theory. Journal of Sichuan Administration College, [J].2009 (1).

[4] Tan Xiaoyan. The Route Choice on the Present Situation and Innovation of Chinese Social

Management on the Period of Transition. The legal System and Society [J].2009 (8).

[5] Tan Xiaohua. Hongkong Social Management Experience is Worth Learning [J]. Study

Monthly.2007 (13). 